\title{
Effects of AMF- and PGPR-root inoculation and a foliar chi- tosan spray in single and combined treatments on powdery mildew disease in strawberry
}

\author{
Aiofe Lowe ${ }^{1}$, Susan M. Rafferty-McArdle ${ }^{2}$ and Alan C. Cassells ${ }^{1}$ \\ ${ }^{1}$ Department of Zoology, Ecology and Plant Science, ${ }^{2}$ Biosciences Institute, National University of Ireland Cork, Ireland \\ e-mail: a.cassells@ucc.ie
}

\begin{abstract}
Trials were carried out using, as a root inoculants, mixed Glomus spp. (G. mossae, G. caledonium, and G. fasiculatum) and Bacillus subtilis FZB24, and the plant activator N, O-carboxymethyl chitosan applied as a foliar spray. The treatments were applied singly and in combinations, on strawberry plants grown out of season in a greenhouse. Both fruit yield and runner production were reduced due to disease. Several of the treatments were found to have significant effects, increasing fruit number and yield, and runner production. Disease symptom severity was lowest in the B. subtilis FZB24 plus chitosan treatment. The treatments giving significantly higher fruit yield/number and runner production were inoculation with $B$. subtilis FZB24, and with B. subtilis FZB24 or AMF combined with chitosan spray. These treatments and a fungicide treatment, gave the same level of disease control.
\end{abstract}

Key words: biological control, Bacillus subtilis, Glomus spp., systemic resistance, plant activators

\begin{abstract}
Abbreviations: AMF, arbuscular mycorrhizal fungi; CSN, N, O-carboxymethyl chitosan; ISR, induced systemic resistance; PGPR, plant growth-promoting rhizobacteria; PVS, peat, vermiculite, sand growth substrate; SAR, systemic acquired resistance.
\end{abstract}

\section{Introduction}

Greenhouse production of strawberry is used in cool temperate regions to extend the cropping season. However, increased warmth and humidity in the greenhouse provide a favorable environment for foliar pathogens (Elad 2000, Paulitz and Bélanger 2001). Powdery mildew, which does not cause significant losses in field production, is a serious concern for strawberry greenhouse producers especially, in the cooler months, when young plants may be severely stunted or killed by the pathogen (Maas 1984, Paulitz and Bélanger 2001). The disease may also affect the fruit, reducing quality and shelf-life. Sphaerotheca macularis, the causal agent of powdery mildew in strawberry, can be controlled by spraying with systemic fungicides but resistance is widespread (Maas 1984). Furthermore, there is a premium for pesticide-free fruit. A potential alternative biological strategy to control the disease is the use of plant defense primers such as ISR-inducing root inoculants ('bioprimers') and chemical plant activators ('primers') (Oostendorp et al. 2001, Anderson et al. 2006). The latter can be applied as one-off treatments or in a spraying programme.

Strawberry is a widely used model to evaluate the beneficial effects of inoculants, mainly for biological control of soil-borne pathogens (Vestberg et al. 2004). Both single inoculants and combinations of bacterial and fungal inoculants have been used (Vestberg et al. 2004). Some inoculants and combinations of inoculants have been shown to be efficacious for the control of soil-borne diseases of strawberry but 


\section{AGRICULTURAL AND FOOD SCIENCE}

A. Lowe et al. (2012) 21: 28-38

there can be a strong growth substrate or seasonal influence (Vestberg et al. 1999; Vestberg et al. 2004).

In the rhizosphere, inoculants may antagonize the target root pathogens and deleterious rhizosphere bacteria (Martin and Bull 2002). The latter action, and the role of inoculants in nutrient re-cycling, may explain some of their beneficial growth effects on the crop (Vestberg and Cassells 2009). Another characterized response to inoculation with PGPR (some Bacillus spp. and Pseudomonas spp.), and to chitosan and some other natural biomolecules, is induction and priming of plant innate immunity syn. systemic resistance (ISR; Heil and Bostock 2002, Anderson at al. 2006, Cassells and Rafferty-McArdle 2012). Following first induction of ISR by inoculants and bioprimers, the genomes of induced cells and daughter cells are imprinted with an epigenetic memory ('primed'), that is, ISR is rapidly up-regulated on pathogen attack (challenge inoculation) and is more effective in controlling some diseases compared with the unprimed plant (Kuc 2001; see review of mechanisms involved in Cassells and Rafferty-McArdle 2012). There are two characterized forms of ISR. Salicylic acid-induced systemic acquired resistance - SAR syn. SA-ISR, is characterized by the expression of the PR-1a gene and is induced by necrotizing pathogens and chemical elicitors (chemical analogues of SA) in the stem and leaves (Spoel et al. 2003). JA+Et-ISR (jasmonic acid + ethylene induced ISR) is characterized by the expression of the PDF1.2 (defensin) gene(s) (Spoel et al. 2003). It has been hypothesized that SA-induced protection is effective against biotrophs and JA+Et-signaling is effective against necrotrophs (Ton et al. 2002, Glazebrook 2005). However, simultaneous induction of both forms of ISR may afford enhanced levels of protection (Ton et al. 2006). There are examples of ISR induction in the absence of the PR-1a and PDF1.2 proteins which is associated with phytoalexin accumulation (Anderson et al. 2006). The use of root inoculants in agriculture and horticulture has been extensively reviewed (Whipps 2004, Anderson et al. 2006, Tuzun and Bent 2006, Walters et al. 2007).

Here, the objective was to evaluate the effect of commercial PGPR and AMF inoculants on strawberry fruit and runner production in greenhouse out-of-season strawberry production with endemic powdery mildew disease to determine whether, or if, biological inoculants or spraying with chitosan alone, or in combined treatments, would give protection against powdery mildew in the out-of-season strawberry crop.

\section{Materials and Methods}

\section{Plant material}

Certified strawberry runners (Fragaria vesca 'Elvira') (Ken Muir Ltd., Clacton-on-Sea, Essex, CO16 9BJ) were planted in the greenhouse into an Irish peat, vermiculite and sand (PVS) [8:1:1 (v: v: v)] (based on Vestberg et al. 1999) medium that had been steam sterilized for one hour at $121^{\circ} \mathrm{C}$ over three consecutive days and allowed to stand for a further day before use. The PVS was fertilized with slow release Osmocote Plus 1g-1 (N: P: K, 15:11:13, Grace Sierra B.V. Herleen, The Netherlands) and limed (agricultural grade lime $\left.\left(\mathrm{CaCO}_{3}\right) 5 \mathrm{gl}^{-1}\right)$ to a $\mathrm{pH}$ of 6.2. The lime and Osmocote were added after final sterilization and cooling (Cassells et al. 1996).

There were an untreated control and eight treatments including a fungicide treatment, as follows:

\section{A control treatment where no inoculants or sprays were applied to the microplants;}

2. Inoculation with a commercial PGPR (Bacillus subtilis FZB24R; ABiTEP Gmbh, D-12489 Berlin, Germany; Krebs et al. 1998). The roots of the strawberry runners were dipped in a suspension of the bacterial formulation ( $5 \times 10^{5}$ spores/g) as advised by the producer. 


\section{AGRICULTURAL AND FOOD SCIENCE}

A. Lowe et al. (2012) 21: 28-38

3. Inoculation with a commercial arbuscular mycorrhizal fungi inoculant (Vaminoc; MicroBio Ltd., Whittlesford, Cambridge, UK) with contains Glomus caledonium, G. fasciculatum and G. mossae (Greipsson and El-Mayas 2000) added at a rate of $1 \mathrm{~g}$ per plant into the runner planting hole (Mark and Cassells 1996);

4. Spraying with $\mathrm{N}, \mathrm{O}$-carboxymethyl chitosan of the strawberry foliage once at the planting of the runners at a concentration of $0.1 \%(w: v)$ in water;

5. Inoculation with a combination of the AMF and PGPR commercial inoculants (application as above);

6. A combination of PGPR inoculation and chitosan spray (as above); the strawberry foliage was sprayed after dipping in the PGPR;

7. A combination of AMF and chitosan spray applied (as above);

8. A combination of AMF and PGPR inoculants and chitosan spray (as above).

Fungicide-treated plants were sprayed with 'Amistar', active ingredient azoxystrobin (Syngenta, Dublin, Ireland) according to the manufacturer's recommendations when disease was detected in the plants.

Greenhouse trials were carried out using the above treatments, consisting of 40 strawberry plants per treatment. The $12 \mathrm{~cm}$ diam. pots, containing a single runner, were placed in a completely randomised block design. Random samples of roots were examined after four weeks to confirm mycorrhizal colonization using the method described by Philips and Hayman (1970). The minimum temperature was maintained at $12{ }^{\circ} \mathrm{C}$ and day length was maintained at $16 \mathrm{~h}$ with illumination from sodium vapour lamps. The duration of the experiment was 60 days.

\section{Fruit and runner production}

Strawberry fruits were harvested three times weekly, with the number of fruits harvested per plant and weight of each fruit recorded. Runner numbers produced per plant in each treatment were recorded at the end of each trial.

\section{Monitoring of powdery mildew disease symptoms}

Disease symptom development was recorded on a twice-weekly basis following the strawberry powdery mildew key of the former UK Agricultural Development and Advisory Service (Anon. 1976). The data was used to illustrate the disease symptom progression and calculate the symptom severity in the respective treatments. The mean \% of the disease symptoms in the plants in each treatment was plotted from the first appearance of symptoms until the end of the trial. The AUDPC (area under the disease-progress curve) calculated based on the integration of the area under the symptom progression curve was used to determine the relative levels of disease in the control and respective treatments (Fry 1978, Jeger and Viljanen-Rollinson 2001).

\section{Statistical analysis}

Analysis of variance (ANOVA) followed by Tukey's Multiple Comparison test was carried out, using GraphPad Prism 2.0 (GraphPad Software Inc., San Diego, USA). 


\section{AGRICULTURAL AND FOOD SCIENCE}

A. Lowe et al. (2012) 21: 28-38

\section{Results}

\section{Mycorrhizal colonization of strawberry plants}

All inoculated plants analysed were found to be colonized by AMF using the grid line intersect method (Giovannetti and Mosse 1980). No colonization was found in the uninoculated plants. No attempt was made to quantify AMF comparative colonization in the AMF treatments over the time course of the experiment.

\section{Susceptibility of plants to powdery mildew}

The symptom progress curves for the control and treatments are shown in Figure 1 (days 0 to 43 ) where the first observation of powdery mildew symptoms (day 0 ) was approximately 20 days after the planting of the runners when disease assessment started. Symptom assessment was based on the key of Anon. (1976). From the first appearance of symptoms, the control (no treatments) showed the greatest susceptibility until day twenty after which it was overtaken by the combined PGPR+AMF+CSN treatment. Also highly symptomed were the PGPR+AMF and AMF treatments, all with over $50 \%$ of plants affected by powdery mildew at $90 \%$ leaf area covered. From day 9 , symptoms developed rapidly in the PGPR+AMF+CSN treatment followed by rapid development in the PGPR+CSN treatment from day 16 . The combination treatment PGPR+AMF, performed less well than either of the single treatments (see below). The PGPR and the CSN treatments, applied singly, delayed symptom development to $37 \%$ and $43 \%$, respectively, at day 43 . Of the treatments, AMF+CSN treatment performed best with just over $20 \%$ of plants with symptoms after 41 days. The fungicide treatment suppressed the powdery mildew symptoms.

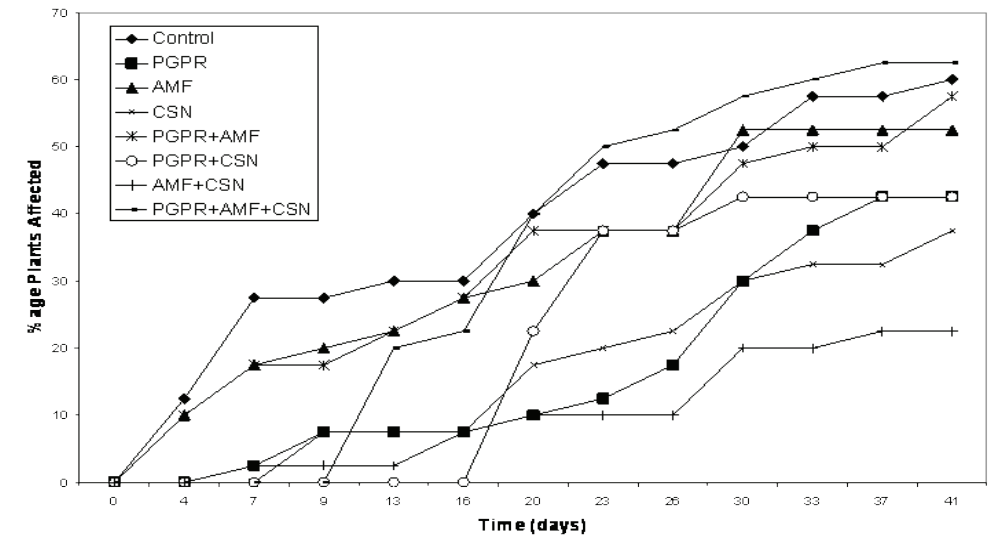

Fig. 1. The disease symptom progression curve of powdery mildew in strawberry (days 0-43) for the treatments based on the disease assessment key of Anon. (1976). Data are for the mean of plants in each treatment reaching $90 \%$ leaf area affected by powdery mildew.

When the AUDPC is calculated there is a ranking of symptom severity from the control with the highest severity (Table 1). The PGPR+AMF+CSN, PGPR+AMF and AMF treatments show little symptom suppression (on average $80 \%$ of the control) whereas the PGPR+CSN, CSN and PGPR treatments form a cluster with on average $49 \%$ of the disease severity of the control. The best treatment in terms of symptom suppression was the AMF+CSN treatment at $23 \%$ of the control followed by the PGPR treatment showing $44 \%$ symptom suppression. No symptoms were detected in the fungicide treatment. 


\section{AGRICULTURAL AND FOOD SCIENCE}

A. Lowe et al. (2012) 21: 28-38

Table 1. Relationship between powdery mildew symptom severity and yield parameters. Treatments with different letters are significantly different at $p<0.05$. AUDPC, area under the disease symptom progress curve - see Fig. 1 (Fry 1978 ).

* Disease symptoms not detected.

\begin{tabular}{llllll}
\hline Treatment & $\begin{array}{l}\text { AUDPC } \\
\text { (arbitrary units) }\end{array}$ & $\begin{array}{l}\text { Relative symptom } \\
\text { severity }\end{array}$ & $\begin{array}{l}\text { Runner no. } \\
\text { (significance) }\end{array}$ & $\begin{array}{l}\text { Fruit no. } \\
\text { (significance) }\end{array}$ & $\begin{array}{l}\text { Fruit yield } \\
\text { (significance) }\end{array}$ \\
\hline Control & 3687 & 100 & $\mathrm{a}$ & $\mathrm{a}$ & $\mathrm{ab}$ \\
PGPR+AMF+CSN & 3238 & 88 & $\mathrm{~b}$ & $\mathrm{ab}$ & $\mathrm{ab}$ \\
PGPR+AMF & 3228 & 88 & $\mathrm{a}$ & $\mathrm{ab}$ & $\mathrm{ab}$ \\
AMF & 3200 & 87 & $\mathrm{a}$ & $\mathrm{ab}$ & $\mathrm{a}$ \\
PGPR+CSN & 2123 & 58 & $\mathrm{a}$ & $\mathrm{bc}$ & $\mathrm{c}$ \\
CSN & 1699 & 46 & $\mathrm{a}$ & $\mathrm{a}$ & $\mathrm{a}$ \\
PGPR & 1633 & 44 & $\mathrm{bc}$ & $\mathrm{bc}$ & $\mathrm{c}$ \\
AMF+CSN & 921 & 23 & $\mathrm{bc}$ & $\mathrm{bc}$ & $\mathrm{c}$ \\
Fungicide & $*$ & $*$ & $\mathrm{c}$ & $\mathrm{c}$ & $\mathrm{bc}$ \\
\hline
\end{tabular}

\section{Runner production}

The effects of the treatments on runner production are shown in Figure 2. Runner production was highest in the fungicide treatment, significantly different to the control. The AMF+CSN, PGPR and PGPR+CSN treatments were next highest; significantly different to the control but not to the fungicide treatment. The PGPR+AMF+CSN treatment was significantly higher than the control but significantly lower than the fungicide treatment. The AMF, CSN and PGPR+AMF treatments were not significantly different from the control.

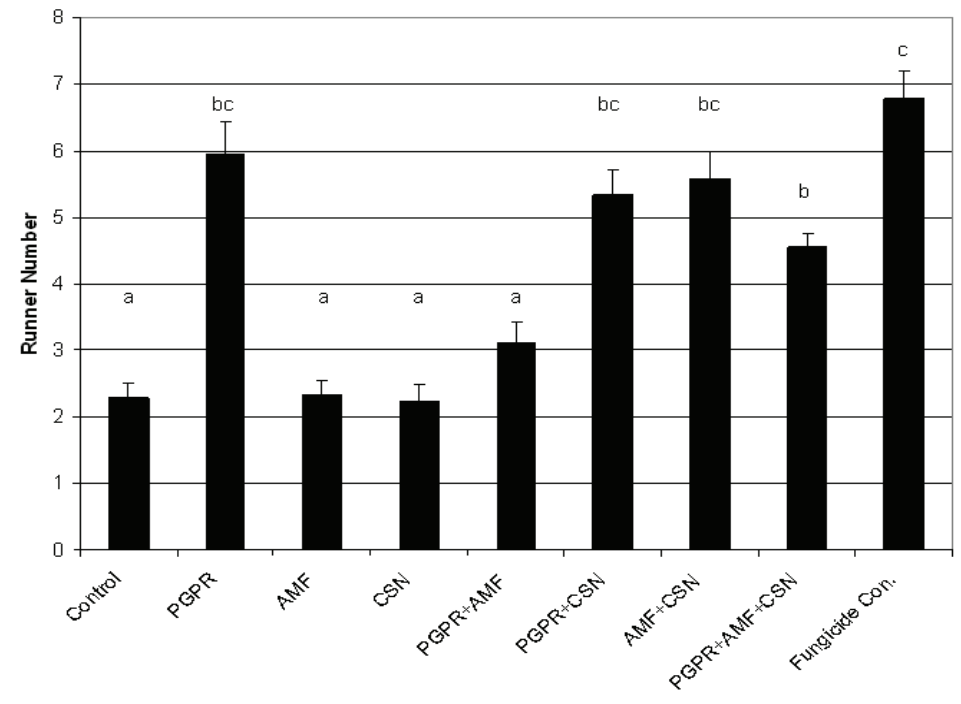

Fig. 2. Mean runner production per plant; treatments differing in letter are significantly different $p<0.05$ according to Tukey's Test (SE, n=40). 


\section{Fruit number}

The AMF+CSN, PGPR and PGPR+CSN treatments gave significantly higher fruit numbers than the control and other treatments and were not significantly different to the fungicide treatment (Fig. 3). The runner numbers in the other treatments were not significantlv higher than the control.

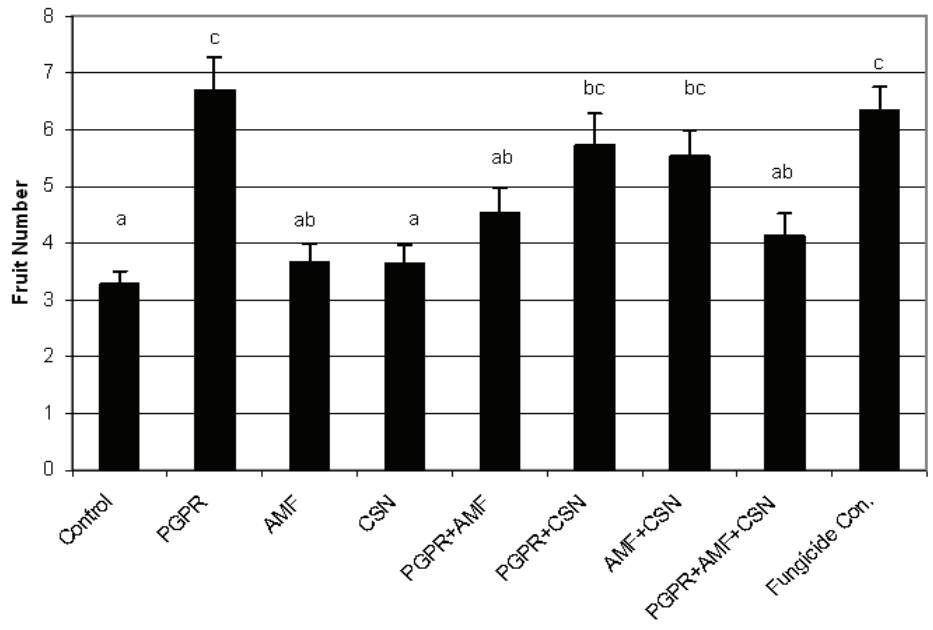

Fig. 3. Mean fruit number per plant; treatments differing in letter are significantly different $p<0.05$ according to Tukey's Test $(\mathrm{SE}, \mathrm{n}=40)$.

\section{Fruit yield}

Treatment with $A M F+C S N, P G P R$ and PGPR+CSN gave significantly higher average fruit yield than the control (Fig. 4). The yield in the fungicide treatment was intermediate between the latter yields and the control but not significantly different to either. Lowest fruit yields were in the AMF and CSN treatments, which were significantly lower than the $A M F+C S N, P G P R, P G P R+C S N$ and fungicide treatments but not significantly different to the control, PGPR+AMF, or PGPR+AMF+CSN treatments (Fig. 4)

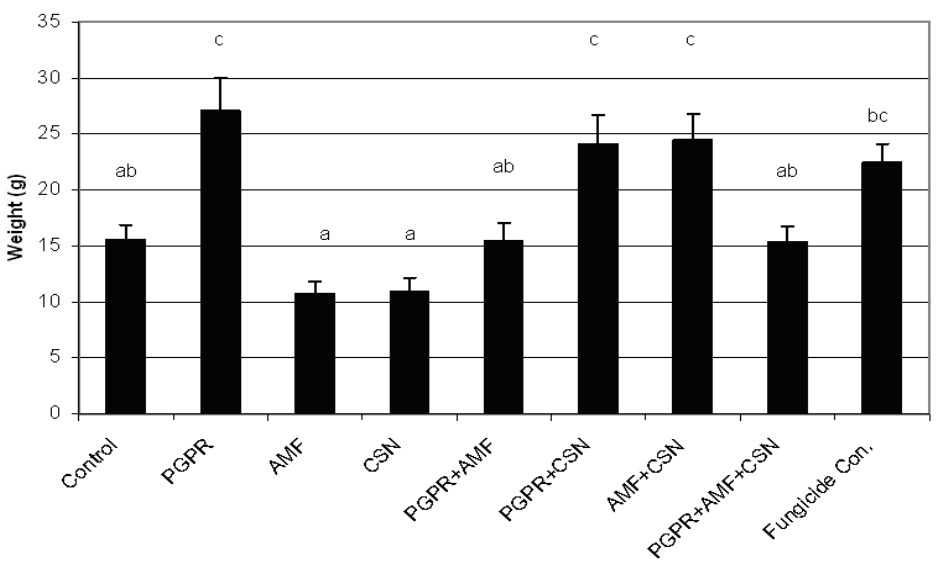

Fig. 4. Mean fruit yield per plant; treatments differing in letter are significantly different $p<0.05$ according to Tukey's Test (SE, $\mathrm{n}=40$ ). 


\section{AGRICULTURAL AND FOOD SCIENCE}

A. Lowe et al. (2012) 21: 28-38

\section{Relationship between disease progression and yield parameters}

The data from the symptom progress curves and the yield data are presented in Table 1 . The curves for most of the treatments were smooth with the exceptions of those for the PGPR+CSN and PGPR+AMF+CSN treatments which initially indicated good symptom suppression but which broke down after 9 and 16 days, respectively (Fig. 1). Overall there was a good comparison between the rankings for symptom severity and yield parameters in the respective treatments. The AMF+CSN and PGPR treatment gave the highest symptom suppression and were not significantly different to the fungicide treatment for all yield parameters. The results for the CSN treatment which gave the third highest symptom suppression were out of agreement with all the other treatments in that symptom suppression was not related to improvement in any of the yield parameters which were not significantly different to the untreated control. There was an anomaly in the relationship between symptom severity and runner number in the PGPR+AMF+CSN treatment in which the number of runners produced was significantly higher than in the control in spite of the high symptom severity.

\section{Discussion}

The pattern of disease development in relation to the ontological development of the crop, influences the effects on yield e.g. early severe reduction of the leaf area index significantly affects the yield potential; whereas late development of severe disease in the crop may have little effect on yield (Fry 1978). Here, the data (Table 1) show a good correlation between relative disease severity based on AUDPC, and runner production, fruit number and fruit yield with the exceptions of the CSN treatment which showed good symptom suppression which was not reflected in the yield parameters and PGPR+AMF+CSN treatment which gave relatively little symptom suppression but significantly higher runner production than in the control. This could be due to foliar toxicity of the CSN spray resulting in redirection of photosynthate from flowering/fruiting into runner production associated early senescence and plant survival.

Examination of the disease progress curves (Fig. 1) show two main patters of disease development. The control, AMF and PGPR+AMF treatments show slow early increase in symptoms with relatively smooth curves till the end of the experiment. The AMF+CSN, PGPR and CSN treatments show slower disease development in the early stages of disease development with the final level of disease in the CSN treatment below that of the other treatments (see comment above re runner production). The PGPR+AMF+CSN and the PGPG+CSN showed good disease suppression initially which broke down after 9 and 16 days, respectively, after the onset of disease.

It is well documented that plants primed by inundation of the roots with biological inoculants and by spraying with chemical activators, show enhanced resistance to pathogens (e.g. Anderson et al. 2006). Many commercial plant activators are synthetic chemicals, analogues of salicylic acid, which act in the signalling in the innate immune response resulting in the expression of PR-1a and other pathogenesisrelated proteins (Anderson et al. 2006, Jones and Dangl 2006). On the other hand, biological inoculants may act in a combination of ways which include promoting plant growth by the release of plant growth regulators; improving plant growth by re-cycling and solubilising minerals; improving resistance to water stress; inhibiting pathogen inoculum in the rhizosphere and inducing and priming the innate immune response in the plant (Vestberg and Cassells 2009, Cassells and Rafferty-McArdle 2012). 


\section{AGRICULTURAL AND FOOD SCIENCE}

A. Lowe et al. (2012) 21: 28-38

Previously, we reported that the commercial AMF and PGPR inoculants evaluated here were effective in controlling soil-borne Verticillum wilt in strawberry in the field (Tahmatsidou et al. 2006). In the latter experiments, combined inoculations did not give significantly different disease control than with either inoculant used singly, implying that pathogen antagonism in the soil by the PGPR inoculant was not the key factor in disease suppression of this root pathogen or that both inoculants equally antagonised the pathogen. The same commercial AMF and Bacillus inoculants were chosen for trial here against foliar powdery mildew in strawberry. Bacillus subtilis FZB24 was selected as the model PGPR inoculant, because spore-forming bacteria have good shelf-life compared with Pseudomonas spp. and generally, unlike Pseudomonas spp., Bacillus spp. both promote plant growth and prime both SA- and JA-ISR (Kloepper et al. 2004). In an unpublished investigation of the inoculation of cabbage (Brassica olaraceae) with Bacillus subtilis FZB24 used here, no specific biomarkers of SA- or JA-ISR were detected but elevated levels of the resistance factor endo-chitinase (powdery mildew walls contain chitin; Belanger at al. 2002) were detected (Janczura and Cassells unpublished). AMF can promote plant growth, through different mechanisms to PGPR, and are reported to induce systemic resistance by SA-ISR (Cordier et al. 1998, Shaul et al. 1999, Pozo and Azcon-Aguilar 2007). PR-5 a biomarker of SA-ISR was detected in potato inoculated the commercial AMF inoculant used here which contained G. mossae and other Glomus spp. (Lowe and Cassells unpublished) agreeing with the findings of Cordier et al. (1998) who reported the presence of PR-1a in tomato plants inoculated with $G$. mossae.

Chemical activators of plant defences have been widely studied (Gatz 1997, Oostendorp et al. 2001, Conrath et al. 2002). Chitosan, used here, has been shown to induce chitinases, associated with non-characterised ISR, and resistance to Eumycota (true fungi whose cell walls contain chitin; Mauch et al. 1984, HammondKosack and Parker 2003) and recently, to promote phytoalexin production (Aziz et al. 2006).

It has been hypothesised that necrotising-pathogens are controlled by JA-ISR response genes, and the more evolved biotrophs by SA-ISR response genes (see review by Glazebrook 2005). Powdery mildew in Arabidopsis has been shown to be resisted by SA-ISR and by combined SA- and JA-ISR (Thomma et al. 2001, Ellis et al. 2002). Hukkanen et al. (2007) have reported that BTH (benzothiadiazole - a SA analogue) induces resistance to powdery mildew in strawberry supporting this hypothesis. A combination of chitosan (N, O-carboxymethyl chitosan) and Vaminoc, and repeated spraying with chitosan, was previously shown to delay the progression of the virulent bio-necrotroph, Phytophthora infestans in potato (Late Blight) (O'Herlihy et al. 2003). Here, AMF inoculation alone gave little protection, but AMF+CSN delayed powdery development, possibly with a priming and/or anti-fungal/plant toxicity activity of CSN [Observation: chemical toxins induce abiotic stress responses which may result in biotic stress cross-tolerance see below]. Chitosan has reported fungicidal activity (Ben-Shalom et al. 2003; Eikemo et al. 2003) and $\mathrm{N}, \mathrm{O}$-carboxymethyl chitosan used here was confirmed to have antifungal activity (Lowe and Cassells unpublished). PGPR alone and PGPR+CSN also gave good disease control.

The plant response to pathogen attack is complex involving activation of both biotic and abiotic stress defences. Recent transcriptomic analyses have indicated that approx. $8 \%$ of the Arabidopsis genome is up-regulated following biotic stress (e.g. Cheong et al. 2002), thus it may be simplistic to talk in terms of the pathogenesis response (the innate immune response/induction of ISR) being based on JA-ISR or SAISR, or indeed a combination of these relatively 'narrow' responses (Cassells and Rafferty-McArdle 2012). While powdery mildew is a foliar pathogen directly affected by ISR, there may be additional but different beneficial rhizospheric effects of the PGPR and AMF biological inoculants used here. It is possible, for example, that the AMF-inoculant protected against water stress due to the pathogen (Belanger et al. 2002); while the PGPR inoculants may have acted against deleterious soil microorganisms (Martin and Bull 2002). 


\section{AGRICULTURAL AND FOOD SCIENCE}

A. Lowe et al. (2012) 21: 28-38

It is well known that environmental factors affect the efficacy of root inoculants (Cook and Baker,1983) and that the plant-inoculant interaction is genotype-dependent at least for AMF in strawberry (Mark and Cassells 1996). This implies that trials must be carried for host and environmental compatibility before inoculants can be claimed to be efficacious for plant genotypes other than those trialled and when used in other environments (Cassells and Rafferty-McArdle 2012). Compared with plant activators, this is a serious barrier to commercialization. Nevertheless when consideration is given to the holistic relationship between PGPR, AMF and plants, in the context of improving plant growth, in increasing biotic and abiotic stress tolerance especially in low input, ecological and subsistence agriculture, and with pro bono research to support the latter; inoculants have the advantage of low application cost and may at least serve an expanding niche market (Fravel 2005).

In conclusion, on the basis of the relative costs of these treatments, the PGPR treatment here would be more cost effective. Furthermore, biocide-producing PGPR may be more durable in coping with adverse edaphic and other environmental factors than AMF inoculants, and consequently may be efficacious across a wider range of crop and soil types than AMF inoculants avoiding the need for expensive trials.

\section{References}

Anderson, A.J., Blee, K.A. \& Yang, K.-Y. 2006. Commercialisation of plant systemic defense activation: theory, problems and successes. In: Tuzun, S. \& Bent, E. (eds) Multigenic and induced systemic resistance in plants. Berlin: Springer. p. 386-414

Anon. 1976. Manual of Plant Growth Stages and Disease Assessment Keys. Strawberry Powdery Mildew Key no. 8.1.1. Ministry of Agriculture, Fisheries and Food (Publications), Pinner HA5 2DT, UK.

Aziz, A., Trotel-Aziz, P., Dhuicq, L., Jeandet, P., Couderchet, M .\& Vernet, G. 2006. Chitosan oligomers and copper sulphate induce grapevine defence reaction and resistance to grey mould and downy mildew. Phytopathology 96: 1188-1194.

Belanger, R.R., Bushnell, W.R., Dik, A.J. \& Carver, T.L.W. 2002. Powdery Mildews. St Louis: APS Press. 292 p.

Ben-Shalom, N., Ardi, R., Pinto, R., Aki, C. \& Fallik, E. 2003. Controlling gray mould caused by Botrytis cinerea in cucumber plants by means of chitosan. Crop Protection 22: 285-290

Cassells, A. C. Mark, G. L. \& Periappuram, C. 1996. Establishment of arbuscular mycorrhizal fungi in autotrophic strawberry culture, in vitro: Comparison with inoculation of microplants invivo. Agronomie 16: 625-632.

Cassells, A.C. \& Rafferty-McArdle, S.M. 2012. Priming of plant defenses by PGPR against fungal and bacterial plant pathogens. In: Maheshwari, D.K. (ed.) Bacteria in Agrobiology: Stress Management. Berlin: Springer-Verlag. p. 1-26.

Cheong, Y.H., Chang, H-S., Gupta, R., Wang, X., Zhu, T. \& Luan, S. 2002. Transcriptional profiling reveals novel interactions between wounding, pathogen, abiotic stress and hormonal responses in Arabidopsis. Plant Physiology 129: $661-677$.

Conrath, U., Pieterse, C.M.J. \& Mauch-Mani, B. 2002. Priming in plant-pathogen interactions. Trends in Plant Science 7: $210-216$.

Cook, K.F. \& Baker, R.J. 1983. Nature and practice of biological control of plant pathogens. St. Paul: APS Press. 539 p.

Cordier, C., Pozo, M.J., Barea, J.M., Gianinazzi, S. \& Gianinazzi-Pearson, V. 1998. Cell defence responses associated with localized and systemic resistance to Phytophthora parasitica induced in tomato by an arbuscular mycorrhizal fungus. Molecular Plant-Microbe Interactions 11: 1017-1028.

Eikemo, H., Stensvand, A. \& Tronsmo, A.M. 2003. Induced resistance as a possible means to control of diseases of strawberry caused by Phytophthora spp. Plant Disease 87: 345-350.

Elad, Y. 2000. Biological control of foliar pathogens by means of Trichoderma harzianum and potential modes of action. Crop Protection 19: 709-714.

Ellis, C., Karafyyllidis, I. \& Turner, J.G. 2002. Constitutive activation of jasmonate signalling in an Arabidopsis mutant correlates with enhanced resistance to Erysiphe cichoracearum, Pseudomonas syringae and Myzus percisae. Molecular Plant Microbe Interaction 10: 1025-1030. 


\section{AGRICULTURAL AND FOOD SCIENCE}

A. Lowe et al. (2012) 21: 28-38

Fravel, D.R. 2005. Commercialisation and implementation of biological control. Annual Review of Phytopathology 43: 337-359.

Fry, W.E. 1978. Quantification of general resistance of potato cultivars and fungicide effects for integrated control of potato late blight. Phytopathology 68: 1650-1655.

Gatz, C. 1997. Chemical control of gene expression. Annual Review of Plant Physiology and Plant Molecular Biology 48: 89-108.

Giovannetti, M. \& Mosse, B. 1980. An evaluation of techniques for measuring vesicular arbuscular mycorrhizal infection in roots. New Phytologist 84: 489-500.

Glazebrook, J. 2005. Contrasting mechanisms of defence against biotrophs and necrotrophic pathogens. Annual Review of Phytopathology 43: 205-227.

Greipsson, S. \& El-Mayas, H. 2000. Arbuscular mycorrhizae of Leymus arenarius on coastal sands and reclamation sites in Iceland and response to inoculation. Restoration Ecology 8: 144-150.

Hammond-Kosack, K.E. \& Parker, J.E. 2003. Deciphering plant-pathogen communication: fresh perspectives from molecular resistance breeding. Current Opinion in Biotechnology 14:177-193.

Heil, M. \& Bostock, R.M. 2002. Induced systemic resistance (ISR) against pathogens in the context of induced plant defences. Annals of Botany 89: 503-512.

Hukkanen, A. T., Kokko, H.I., Buchala, A.J., McDougall, G.J., Stewart, D., Karenlampi, S.O. and Karjalainen, R.O. 2007. Benzothiadiazole induces the accumulation of phenolics and improves resistance to powdery mildew in strawberries. Journal of Agricultural and Food Chemistry 55: 1862-1870.

Jeger, M.J. \& Viljanen-Rollinson, S.L.H. 2001. The use of the area under the disease-progress curve (AUDPC) to assess quantitative disease resistance in crop cultivars. Theoretical and Applied Genetics 102: 32-40.

Jones, J.D.G. \& Dangl, J.L. 2006. The plant immune system. Nature 444: 323-329.

Kloepper, J.W., Ryu, C-M. \& Zhang, S. 2004. Induced resistance and promotion of plant growth by Bacillus spp. Phytopathology 94: 1259-1266.

Krebs, B., Hoding, B., Kubart, S. M., Workie, A., Junge, H., Schmiedeknecht, G., Grosch, R., Bochow, H. \& Hevesi, M. 1998. Use of Bacillus subtilis as biocontrol agent. I. Activities and characterization of Bacillus subtilis strains. Journal of Plant Diseases and Protection 105:181-197.

Kuc, J. 2001. Concepts and direction of induced systemic resistance in plants and its application. European Journal of Plant Pathology 107: 7-12.

Maas J.L. 1984. Compendium of strawberry diseases. St. Paul, Minnesota: APS. 138 p.

Mark, G. L. \& Cassells, A. C. 1996. Genotype-dependence in the interaction between Glomus fistulosum, Phytophthora fragariae and the wild strawberry (Fragaria vesca). Plant \& Soil 185: 233-239.

Martin, F.N. \& Bull, C.T. 2002. Biological approaches for control of root pathogens of strawberry. Phytopathology 92: $1356-1362$.

Mauch, F., Hadwiger, L.E. \& Boller, T. 1984. Ethylene: symptom, not signal for the induction of chitinase and $\beta-1$, 3-glucanase in pea pods by pathogens and elicitors. Plant Physiology 76: 607-611.

O'Herlihy, E.A., Duffy, E.M. \& Cassells, A.C. 2003. The effects of arbuscular mycorrhizal fungi band chitosan sprays on yield and late blight resistance in potato crops from microplants. Folia Geobotanica 38: 201-208

Oostendorp, M., Kunz, W., Dietrich, B \& Staub, T. 2001. Induced disease resistance by chemicals. European Journal of Plant Pathology 107: 19-28.

Paulitz, T.C. \& Bélanger, R.R. 2001. Biological control in greenhouse systems. Annual Review of Phytopathology 39: 103-133.

Philips, J.M. \& Hayman, D.S. 1970. Improved procedures for clearing roots and staining parasitic and vesicular-arbuscular mycorrhizal fungi for rapid assessment of infection. Transactions of the British Mycological Society 55: $158-161$.

Pozo, M. J. \& Azcon-Aguilar, C. 2007. Unravelling mycorrhizal-induced resistance. Current Opinion in Plant Biology 10: 393-398.

Shaul, O., Galili, S., Volpin, H., Ginzberg, I., Elad, Y., Chet, I. \& Kapulnik, Y. 1999. Mycorrhizal-induced changes in disease severity and PR protein expression in tobacco leaves. Molecular Plant-Microbe Interactions 12: 1000-1007. 


\section{AGRICULTURAL AND FOOD SCIENCE}

A. Lowe et al. (2012) 21: 28-38

Spoel, S.N., Koorneef, A., Claessens, S.M.C., Korzelius, J.P., Van Pelt, J.A., Mueller, M.J., Buchala, A.J., Metraux, J-P., Brown, R., Kazan, K., van Loon, L.C., Dong, X. \& Pieterse, C.M.J. 2003 . NPR1 modulates cross talk between salicylateand jasmonate-dependent defense pathways through a novel function in the cytosol. The Plant Cell 15: 760-770.

Tahmatsidou, V., O'Sullivan, J., Cassells, A.C., Voyiatzis, D. \& Paroussi, G. 2006. Comparison of AMF and PGPR inoculants for the suppression of Verticillium wilt of strawberry (Fragaria x vesca cv. Selva). Applied Soil Ecology 32: 316-324.

Thomma, B., Penninckx, I., Broekaert, W.F. \& Cammue, B. 2001. The complexity of disease signalling in Arabidopsis. Current Opinion in Immunology 13: 63-68.

Ton, J., Van Pelt, J.A., Van Loon, L.C. \& Pieterse, C.M.J. 2002. Differential effectiveness of salicylate-dependent and jasmonate/ethylene-dependent induced resistance in Arabidopsis. Molecular Plant-Microbe Interactions 15: 27-34.

Ton, J., Pieterse, C.M.J. \& Van Loon, L.C. 2006. The relationship between basal and induced resistance in Arabidopsis. In: Tuzun, S. \& Bent, E. (eds.) Multigenic and Induced Systemic Resistance in Plants .Berlin: Springer-Verlag. p. $197-223$.

Tuzun, S. \& Bent, E. 2006. Multigenic and induced systemic resistance in Plants. Berlin: Spinger-Verlag. 540 p.

Vestberg, M and Cassells, A. C. 2009. The use of AMF and PGPR inoculants singly and combined to promote microplant establishment, growth and health. In: Varma, A. and Kharkwal, A. C. (eds.) Symbiotic Fungi: Principles and Practice. Berlin: Springer-Verlag. p. 337-361.

Vestberg M., Kukkonen S., Neuvonen E-L. \& Uoskainen M. 1999. Mycorrhizal propagation of micropropagated strawberry-case study on mineral soil and on mined peat bog. In: Cassells A.C., Doyle B.M., Curry R.F. (eds.) Proceedings of the international symposium on methods and markers for quality assurance in micropropagation Leuven: ISHS. p. $297-304$.

Vestberg, M., Kukkonen, S., Saari, K., Parikka, P., Huttunen, J. 2004. Microbial inoculation for improving the growth and health of micropropagated strawberry. Applied Soil Ecology 27: 243-258.

Walters, D., Newton, A \& Lyon, G. 2007. Induced Resistance for Plant Defence. New York: Wiley. 272 p.

Whipps, J.M. 2004. Prospects and limitations for mycorrhizas in biological control of root pathogens. Canadian Journal of Botany 82: 1198-1227. 